\title{
Seed Germination and Early Growth Responses of Hyssop, Sweet Basil and Oregano to Temperature Levels
}

\author{
Sajad MIJANI ${ }^{1}$, Samieh ESKANDARI NASRABADI ${ }^{2 *}$, Hadi \\ ZARGHANI',Mohammad GHIAS ABADI'
}

\author{
${ }^{1}$ DepartmentAgronomy, Ferdowsi University of Mashhad, Faculty of Agriculture, Mashhad, Iran; sajad.mijani@stu.um.ac.ir \\ ${ }^{2}$ Department Agronomy and Soil science, University of New England, School of Environmental and Rural Science, New England, \\ School of Environmental and Rural Science, Armidale, NSW 2351, Australia; seskanda@myune.edu.au ("corresponding author)
}

\begin{abstract}
The objectives of this survey were to determine the effect of temperature on germination and seedling growth of Hyssop (Hyssopus officinalis L.), Sweet basil (Ocimum basilicum L.) and Oregano (Origanum vulgare L.) (Lamiaceae family) as well as comparing species regarding germination behavior and growth characteristics. Seeds were germinated on a temperature-gradient bar varying between 5 and $40{ }^{\circ} \mathrm{C}$ (with $5^{\circ} \mathrm{C}$ intervals). Results indicated that the highest germination percentage of hyssop (92-98\%), sweet basil (86-90\%) and oregano $(74-77 \%)$ occurred at $20-30{ }^{\circ} \mathrm{C}, 25-30{ }^{\circ} \mathrm{C}$ and $20-30{ }^{\circ} \mathrm{C}$, respectively; therefore, moderate and warm temperatures are proper for germination of all species. In all species the maximum germination rate obtained at $30{ }^{\circ} \mathrm{C}$. Among all species, Day $10 \%$ of Sweet basil Germination had the lowest value, which indicates faster germination. The cardinal temperatures (base, optimum and ceiling or maximum) were estimated by the segmented model. Base temperature $(\mathrm{Tb})$ was calculated for hyssop, sweet basil and oregano as 3.42 , 5.70 and $5.46^{\circ} \mathrm{C}$, respectively. Optimal temperature (To) calculated for all species was approximately $30^{\circ} \mathrm{C}$, So warmer temperatures are much more proper for them. The species showed different maximum temperatures (Tm) from 42.91 (Oregano) to $48.05^{\circ} \mathrm{C}$ (Hyssop). In Hyssop and Sweet basil optimum growth of seedlings were observed at $30^{\circ} \mathrm{C}$ while Oregano reached its best growth at $25^{\circ} \mathrm{C}$. The difference between maximum and minimum temperatures of germination knowing as temperature range (TR) index could show adaptation capability to broad sites for planting and domestication. Regarding this index Hyssop stood in the first place.
\end{abstract}

Keywords: cardinal temperatures, Hyssopus officinalis L., Lamiaceae, medicinal plant, Ocimum basilicum L., Origanum vulgare

\section{Introduction}

Germination necessities are species-specific and the expansion and rate at which the process takes place in non-dormant seeds, is affected by several environmental factors, such as light, oxygen, water and temperature (De Villiers et al., 2002). Temperature range as one of the most significant factors affecting the seed germination process is characterized by cardinal temperatures, i.e., base temperature $(\mathrm{Tb})$ below which it doesn't germinate, ceiling temperature $(\mathrm{Tc})$ above which the germination is zero and optimum temperature (or range of temperatures) (To) at which the germination rate is the highest (Phartyal et al., 2003). Generally temperatures below the optimum result in progressively poorer germination (Nykiforuk and Flanagen, 1994) while germination rate is usually increased linearly by temperature, at least within a well-defined range and declines sharply at higher temperatures (Kamkar $e t$ al., 2006; Mwale et al., 1994; Ramin, 1997). Temperature affects the onset, potential and rate of germination (Flores and Briones, 2001; Roberts, 1988), and is thereby always the most critical factor determining success or failure of plant establishment (Kader and Jutzi, 2004)

Cardinal temperatures (minimum, optimum and maximum) determine the range of temperatures at which a particular species seeds can germinate. Species dispersion area, suitable time and place for growing can be estimated by knowing cardinal temperatures. Aromatic plants have wide range of economic uses for many centuries; cooking, medicine, cosmetic, fuel are some of them. Knowing germination procedure will be very useful in growing medicinal crops as this information will help in domestication and successful establishment of the seedlings particularly when there are wild species. Lamiaceae family (Mint Family) is famous for its species richness with medicinal properties, which have been used since early times (Kocabas and Karaman, 2001) as well as many precious species belonging to Papilionaceae family. Little information is known about optimal germination conditions of many labiates while there is a potential commercial interest for them (Estrelles et al., 2010). Since cardinal temperature is very important for seed germination and there is not any comprehensive information about cardinal temperatures and the response of seed germination to varying temperatures for Hyssop (Hyssopus officinalis L.), Basil (Ocimum basilicum L.) and Oregano (Origanum vulgare L.) from Lamiaceae family, the goal of this study was to probe the effects of temperature on seed germination and seedling growth in these medicinal plants and to calculate the base $(\mathrm{Tb})$, optimum $(\mathrm{To})$ and ceiling temperature $(\mathrm{Tc})$ for them. 
Materials and methods

Source of seeds

Seeds of three species used in study were collected in 2011 from the herbal garden of medicinal plants, Research Station of Faculty of Agriculture, Ferdowsi University of Mashhad located in central part of the Khorasan Razavi province, Iran. No fertilizer was used during plant growth and they were irrigated.

\section{Germination test}

Full-grown and complete seeds preferred for germination test were selected after one year of storing in dark condition with temperature just about $25^{\circ} \mathrm{C}$. Firstly sodium hypochlorite $(\mathrm{NaOCl}) 1 \%$ was used to sterilize surfaces of the mature seeds for 5 minutes followed by careful rising with pure water. For each experiment, 25 seeds were placed in moistened double-layered Whatman no. 1 filter paper (deionized water was used) in Petri dishes. The Petri dishes were insulated by means of Parafilm to prevent the seeds from drying out and small amounts of water were added as needed. Within a fortnight germination response to temperature was assessed over the range 5-45 ${ }^{\circ} \mathrm{C}$, at $5^{\circ} \mathrm{C}$ intervals using dark germinators with $60-70 \%$ relative humidity. Germinated seedlings were counted and removed day by day. A seed was considered as germinated once it's radicle stood out through the seed coat at least 5 $\mathrm{mm}$. Counting finished when no seed germinated during 4 successive days.

Total germination percentage and germination rate index were calculated for each species. Total germination at each temperature was calculated from the total number of seeds germinated divided by the total number of seeds. Maguire (1962) method was used to calculate mean germination rate index:

Germination Rate Index $=(\mathrm{Ni} / \mathrm{Di})$ where $\mathrm{Ni}$ is the germinated seed number on the $\mathrm{i}^{\text {th }}$ day and $\mathrm{Di}$ is the number of days from the commencement of the germination test to the $\mathrm{i}^{\text {th }}$ day. Cumulative curve of germination percent was illustrated in response to the time (day), since the experiment started. Then by using these curves was accounted the experiment start time until receiving the 10 (D10), 50 (D50) and 90\% (D90) of germination (Soltani et al., 2002). Seedling shoot length was measured from five seedling 10 days after germination commencement.

\section{Statistical analysis}

In order to assess the impacts of different temperature levels on germination behavior of mentioned species analysis of variance (ANOVA) was performed as a standard procedure for complete randomized design. For each species at different temperatures, the data was analyzed. Prior to statistical analysis a normality test was done for all data and percentage data were transformed $\left(\arcsin \sqrt{\frac{x}{100}}\right)$

when required. The LSD test was used for mean comparisons with $\alpha=0.05$.

\section{Modeling}

Cardinal temperatures were obtained by fitting a segmented model (Soltani et al., 2006) (Equation1) to data collected for three medicinal species against temperature. Germination rate was calculated as the inverse of the number of days $\left(\mathrm{d}^{-1}\right)$ to reach $50 \%$ germination (D50). Model fitted by using the non-linear regression procedure of Sigma Plot 11.

$$
\mathrm{f}=\mathrm{a}_{1}+\mathrm{b}_{1} \mathrm{~T}(\mathrm{~T}<\mathrm{Topt})
$$

$\mathrm{f}=\mathrm{a}_{2}+\mathrm{b}_{2} \mathrm{~T}(\mathrm{~T}>\mathrm{Topt})$

There are four parameters in the bilinear approach, $\mathrm{a}_{1}$, $b_{1}, a_{2}$ and $b_{2}$, from which the cardinal temperatures can be derived.

Difference of maximum and minimum temperature for germination known as Temperature Range (TR) (Equation 2) shows the germination ecological range of species.

$\mathrm{TR}=\mathrm{T}_{\mathrm{m}}-\mathrm{T}_{\mathrm{b}}$

In which $T_{m}$ and $T_{b}$ indicate temperatures above and below which germination will be stopped.

\section{Results and discussion}

\section{Effects on total and germination rate}

The effect of temperature was significant $(\mathrm{P}<0.05)$ on the total germination percentage of all species (Tab. 1). Almost all the seeds of three species germinated at $10-40{ }^{\circ} \mathrm{C}$ under darkness, However, only hyssop seeds germinated $(45.33 \%)$ at the coolest temperature $\left(5^{\circ} \mathrm{C}\right)$. Probably germination absence of two other species at $5^{\circ} \mathrm{C}$, notes to the short period of 14 days because seed germination reduction at low temperatures is extremely related to germination rate decrease (Finch-Savage and Phelps, 1993). On the other hand, medicinal species usually are wild plants that still have not been domesticated like modified crops and have many undesirable characteristics that must be overcome throughout the time. Some researchers reported that wild plants presented lower germination rate and germination percentage than breeding crops (Evans, 1996; Otero-Arniaz et al., 2003; Rojas-Aréchiga et al. 2001).

Results showed that the highest germination percentage of hyssop (92-98.66\%), sweet basil (86.66-90.66\%) and oregano (74.66-77.33\%) occurred at 20-30, 25-30 and $20-30{ }^{\circ} \mathrm{C}$, respectively (Tab. 1 ). This means that, moderate and warm temperatures are suitable for germination of all species. Total germination percentages for hyssop, sweet basil and oregano did not differ significantly over the range of $20-25,25-30$ and $20-30{ }^{\circ} \mathrm{C}$, respectively. Average germination of hyssop and sweet basil at high temperature $\left(40^{\circ} \mathrm{C}\right)$ shows their ability for germination and likely growth in warmer areas. 
464

Tab. 1. Temperature effects on seed germination percentage

(\%) and germination rate of Hyssop, Sweet basil and Oregano

\begin{tabular}{|c|c|c|c|c|c|c|c|c|c|}
\hline \multicolumn{10}{|c|}{ Germination Percentage (\%) } \\
\hline \multirow[t]{2}{*}{ Species } & \multicolumn{8}{|c|}{ Temperature $\left({ }^{\circ} \mathrm{C}\right)$} & $\begin{array}{c}\text { LSD } \\
(\mathrm{p}<0.05)\end{array}$ \\
\hline & 5 & 10 & 15 & 20 & 25 & 30 & 35 & 40 & \\
\hline Hyssop & $\begin{array}{c}45.33 \\
\mathrm{D}\end{array}$ & $\begin{array}{c}81.33 \\
\text { C }\end{array}$ & $\begin{array}{c}88 \\
\text { BC }\end{array}$ & $\begin{array}{c}98.66 \\
\text { A }\end{array}$ & $\begin{array}{c}97.33 \\
\mathrm{~A}\end{array}$ & $92 \mathrm{~B}$ & $\begin{array}{c}85.33 \\
\text { BC }\end{array}$ & $\begin{array}{c}45.33 \\
D\end{array}$ & 8.82 \\
\hline $\begin{array}{c}\text { Sweet } \\
\text { basil }\end{array}$ & $-\dagger$ & $\begin{array}{c}30.66 \\
E\end{array}$ & $\begin{array}{c}74.66 \\
\text { C }\end{array}$ & $\begin{array}{c}82.66 \\
\text { BC }\end{array}$ & $\begin{array}{c}86.66 \\
\mathrm{AB}\end{array}$ & $\begin{array}{c}90.66 \\
\mathrm{~A}\end{array}$ & $\begin{array}{c}70.66 \\
C D\end{array}$ & $\begin{array}{l}56 \\
\mathrm{D}\end{array}$ & 9.54 \\
\hline Oregano & - & $\begin{array}{c}14.66 \\
\text { C }\end{array}$ & $\begin{array}{c}62.66 \\
\text { B }\end{array}$ & $\begin{array}{c}74.66 \\
\mathrm{AB}\end{array}$ & $\begin{array}{c}74.66 \\
\mathrm{AB}\end{array}$ & $\begin{array}{c}77.33 \\
\mathrm{~A}\end{array}$ & $\begin{array}{c}61.33 \\
\text { B }\end{array}$ & $\begin{array}{c}21.33 \\
\text { C }\end{array}$ & 6.66 \\
\hline
\end{tabular}

\begin{tabular}{|c|c|c|c|c|c|c|c|c|c|}
\hline \multicolumn{10}{|c|}{ Germination Rate (seed/day) } \\
\hline \multirow[t]{2}{*}{ Species } & \multicolumn{8}{|c|}{ Temperature $\left({ }^{\circ} \mathrm{C}\right)$} & $\begin{array}{c}\text { LSD } \\
(\mathrm{p}<0.05)\end{array}$ \\
\hline & 5 & 10 & 15 & 20 & 25 & 30 & 35 & 40 & \\
\hline Hyssop & $1.17 \mathrm{~F}$ & $2.92 \mathrm{E}$ & $4.90 \mathrm{D}$ & $7.81 \mathrm{C}$ & $10.47 \mathrm{~B}$ & $13.94 \mathrm{~A}$ & $9.10 \mathrm{BC}$ & $4.90 \mathrm{D}$ & 1.58 \\
\hline $\begin{array}{c}\text { Sweet } \\
\text { basil }\end{array}$ & $-\dagger$ & $0.97 \mathrm{E}$ & $6.87 \mathrm{D}$ & $12.53 \mathrm{~B}$ & $13.92 \mathrm{~B}$ & $18.95 \mathrm{~A}$ & $10.06 \mathrm{C}$ & $7.44 \mathrm{D}$ & 1.94 \\
\hline Oregano & - & $0.40 \mathrm{E}$ & $3.9 \mathrm{D}$ & $4.97 \mathrm{C}$ & $5.80 \mathrm{BC}$ & $10.75 \mathrm{~A}$ & $6.28 \mathrm{~B}$ & $1.02 \mathrm{E}$ & 0.93 \\
\hline
\end{tabular}

Any two means not sharing a letter within row differ significantly

(LSD test, $\mathrm{P}<0.05$ ). $†$ : Dash for each temperature indicates that

was not analyzed by ANOVA and mean comparison

Putievsky (1983) reported that germination of sweet basil was not sensitive to temperature, and germinated well over a wide range of temperatures. Results of Thanos et al. (1995) indicated that three plants of lamiaceae family including thyme (Coridothymus capitatus), savory (Satureja thymbra) and oregano (Origanum vulgare spp. Hirtum) showed germination percentage to a greater extend at a relatively temperature range, with an optimum around 15$20^{\circ} \mathrm{C}$. Furthermore, according to their results oregano had an absolute light requirement in their experiment while, in present survey it germinated well under darkness which is consistent with previous results showing Oregano seeds can germinate equally well in darkness or under white light (Grime et al., 1988).

Estrelles et al. (2010) reported that germination of two species of Sideritis (chamaedryfolia and pungens) from Labiateae family in darkness were noticeably higher than in well lighted condition. Germination rate index (seed/ day) can vary from 0 to 100 , which higher values represent faster germination rate. Since in present study 25 seeds were used for each replication, this index was between 0 and 25. For all species, the maximum germination rate obtained at $30{ }^{\circ} \mathrm{C}$. However, the highest range of germination rate for hyssop (9.10-13.94), sweet basil (10.06-18.95) and oregano (5.80-10.75) occurred at 25-35, 20-35 and $25-35^{\circ} \mathrm{C}$ respectively (Tab. 1 ). Among these species, sweet basil had greatest germination rate. For three species, the highest germination rate occurred in moderate and warm temperatures like germination percentage, indicating that these temperatures may be optimum range of temperatures for their germination.

\section{Time to D10, D50 and D90\% of Germination}

Germination rate index is obtained from the sum of the daily germination rate and cannot be used to measure start, middle and final time of all germinated seed doubtless, germination rate reaching D10 (start), D50 (middle) and D90 (final) will be better predictors of the temperature effects on germination rate. Obviously, temperature had a significant effect on D10, D50 and D90 $(\mathrm{P}<0.05)$. As shown in Fig. 1 number of days to reach D50 and D90 of germination changed like a U-shaped curve for all species at tested temperature ranges. However, there was also Ushaped curve for Oregano germination rate (D10). Similarly, D10, D50 and D90 of all species showed a decline by increasing temperature up to $30^{\circ} \mathrm{C}$ at which they reached the minimum and subsequently increased thereafter. Olivier and Annandale (1998) stated that U-shaped curve is a typical reaction to temperature for many developmental stages, including germination. Among all species, D10 of Sweet basil had the lowest value, which indicates faster germination. Regarding D10 there was no significant difference in all species within the range of 20 to $40{ }^{\circ} \mathrm{C}$. While for hyssop and oregano D10 values observed at 30 ${ }^{\circ} \mathrm{C}$ had considerable differences compared with other temperature levels. The highest day of D10, D50 and D90 was between 5 and $10^{\circ} \mathrm{C}$ for all three species. As mentioned above, germination rate decreases at low temperatures result in seed germination reduction. The lowest value of $\mathrm{D} 50$ was related to sweet basil as well. Within the range of $15-40^{\circ} \mathrm{C}$ hyssop and sweet basil showed final germination (D90) in less than 5, while oregano final germination happened in less than 7 days at $40^{\circ} \mathrm{C}$. Based on D50 and D90 values, for hyssop, sweet basil and oregano it seems that $25-30^{\circ} \mathrm{C}, 25-30^{\circ} \mathrm{C}$ and $30^{\circ} \mathrm{C}$ are optimum temperatures for germination, respectively.

\section{Cardinal temperatures of germination}

The cardinal temperatures (base, optimum and ceiling or maximum) were determined by linear regression analysis of the germination rate (1/D50) against temperature. According to the results of the segmented model, cardinal temperatures were different among species (Tab. 2). Base temperature $\left(T_{b}\right)$ was calculated for hyssop, sweet basil and oregano as $3.42,5.70$ and $5.46{ }^{\circ} \mathrm{C}$, respectively. As shown in the current study, hyssop had lowest $\mathrm{Tb}$ this means that this species could germinate in lower temperatures rather than two other species. Optimal temperature was calculated for all species approximately $30^{\circ} \mathrm{C}$, So warmer temperatures are proper for faster germination of all species. Of course, it is not an unexpected result as these three species are considered as tropical plants. It can be inferred that germination as the first step in life cycle shows ability of plants in other steps of life. It is worth to mention that species showed different maximum temperatures from 42.91 (Oregano) to $48.05^{\circ} \mathrm{C}$ (Hyssop). 

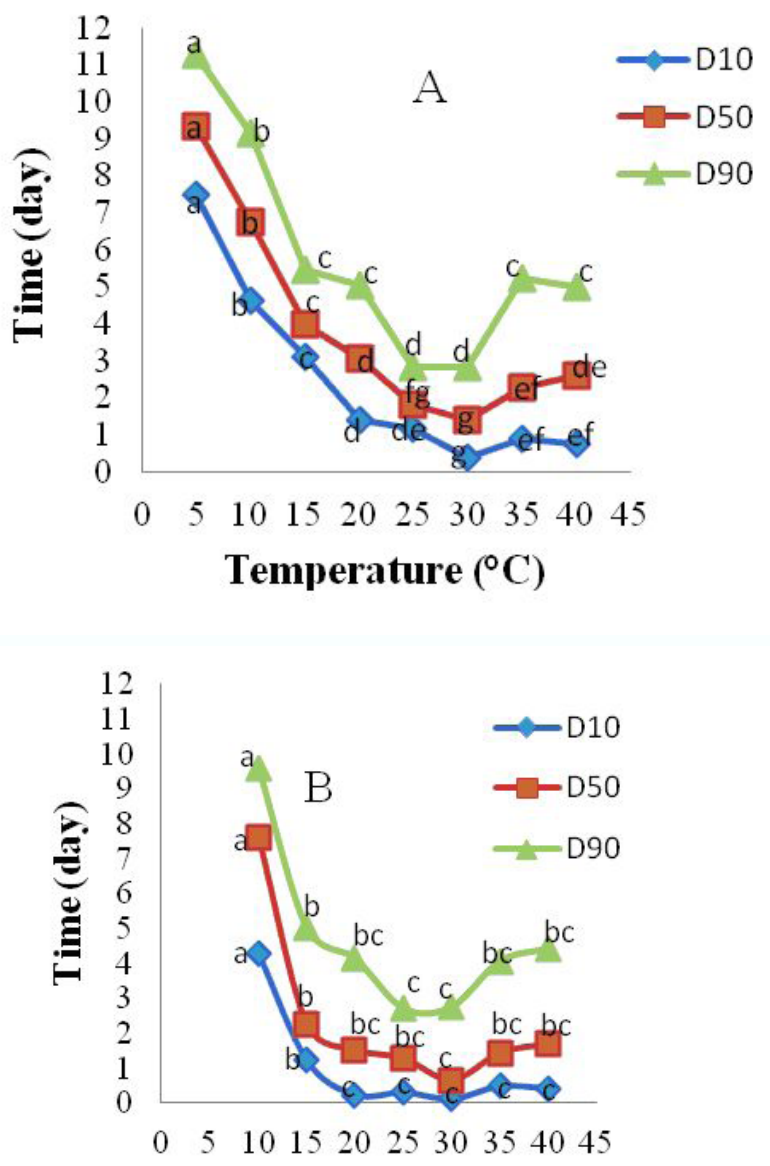

Temperature $\left({ }^{\circ} \mathrm{C}\right)$

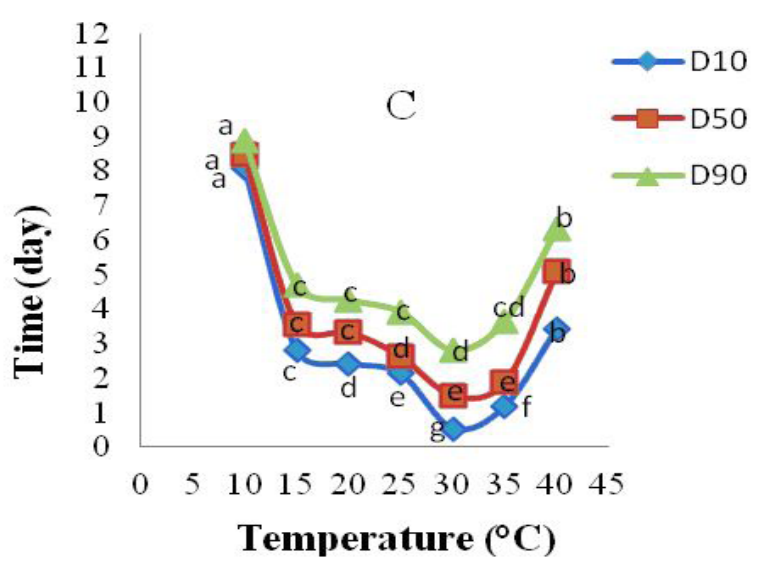

Fig. 1. Comparison of days to D10, D50 (-) and D90\% ( $\boldsymbol{\Delta})$ of germination for (A) hyssop, (B) sweet basil and (C) oregano Significant at $\alpha=0.05$

Brändel (2006) reported that the minimum temperature for germination of Mentha aquatica was $9{ }^{\circ} \mathrm{C}$ and 12 ${ }^{\circ} \mathrm{C}$ in Lycopus europaeus and Stachys palustris (three species from lamiaceae family), and a maximum temperature of $33^{\circ} \mathrm{C}$ for L. europaeus and $36^{\circ} \mathrm{C}$ for M. aquatica and $S$. palustris. For majority of plant species, optimum and ceil- ing temperatures have been reported from ranges of 15-30 ${ }^{\circ} \mathrm{C}$ and $30-40{ }^{\circ} \mathrm{C}$, respectively (Copeland and McDonald, 1995). Other studies have shown that the cardinal temperatures for germination depend on species (Ann and Binning, 1987) and genetic and environmental conditions at which plant grows (Iannucci et al., 2000).

Temperature range (TR) index is derived from difference between $T_{m}$ and $T_{b}$. This means that, each species has high TR is able to germinate in wide range of temperatures. According to the result of this experiment hyssop had the highest TR $\left(44.63^{\circ} \mathrm{C}\right)$.

Tab. 2. Cardinal temperatures $\left({ }^{\circ} \mathrm{C}\right)$ of hyssop, sweet basil and oregano on the segmented model

\begin{tabular}{cccccc} 
Species & $\mathrm{T}_{\mathrm{b}}$ & $\mathrm{T}^{\circ}$ & $\mathrm{T}_{\mathrm{m}}$ & $\mathrm{R}^{2}$ & $\begin{array}{c}\text { Temperature } \\
\text { Range } \\
\left(\mathrm{T}_{\mathrm{m}}-\mathrm{T}_{\mathrm{b}}\right)\end{array}$ \\
\hline Hyssop & 3.42 & 30.10 & $48.05^{* *}$ & 0.94 & $44.63^{* *}$ \\
\hline Sweet basil & 5.70 & 30.04 & 46.4 & 0.98 & 40.7 \\
\hline Oregano & 5.46 & 30.17 & $42.91^{* *}$ & 0.91 & $37.45^{* *}$ \\
\hline
\end{tabular}

$\mathrm{Tb}, \mathrm{To}$ and $\mathrm{Tm}$ represent base, optimum and maximum (ceiling) temperatures.

Fig. 2 illustrates that the growth of species seedlings were highly affected by temperature levels. Response of shoot height to various temperature levels was fitted by the third-order polynomial regression for hyssop ( $22=$ $0.94)$, oregano $(\mathrm{R} 2=0.76)$ and sweet basil $(\mathrm{R} 2=0.93)$. Totally, within temperature ranges of $15-40{ }^{\circ} \mathrm{C}$ sweet basil seedlings reached the highest height followed by hyssop and oregano, it can be concluded that sweet basil can grow faster and utilize supplies well; therefore, compared with other plants (Intercropping) or weeds it will show better competitive behavior, however, proving this claim needs more experiments in this field. In hyssop and sweet basil optimum growth of seedlings were observed at $30^{\circ} \mathrm{C}$ while oregano reached its highest growth at $25^{\circ} \mathrm{C}$. It seems that besides germination process species growth will also improve by increasing temperature. Chang et al. (2005) declared that sweet Basil foliar biomass, dry matter content, and volatile oil content were greatest when temperature remained constant at $25^{\circ} \mathrm{C}$ compared with constant temperatures of 15 or $30^{\circ} \mathrm{C}$. Putievsky (1983) showed that sweet basil germinated well over a wide range of temperatures; however, with increasing temperatures the height of 
plants was increased, and the highest dry matter was obtained at $30^{\circ} \mathrm{C}$.

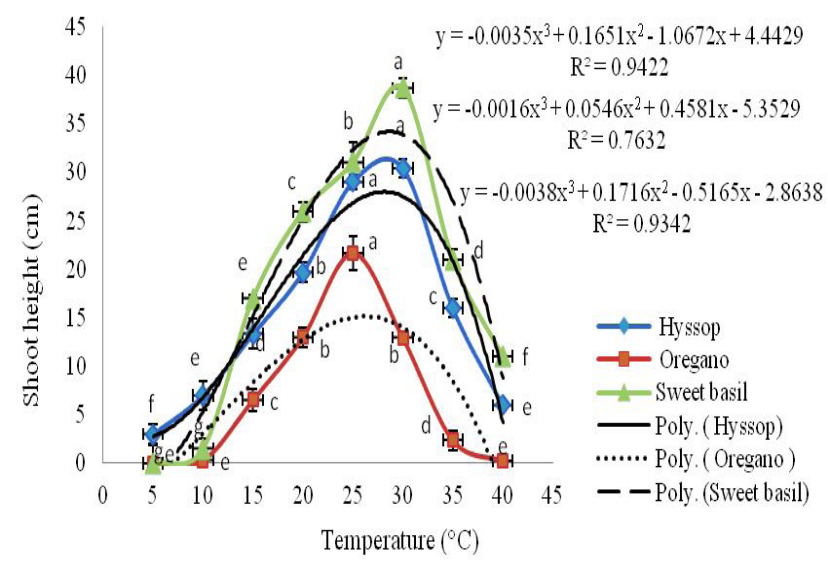

Fig. 2. Effect of temperature on seedlings growth of hyssop $(\boldsymbol{\Lambda})$, sweet basil and oregano (-). Fitting the third-order polynomial regression with $\mathrm{R} 2$ of $0.94,0.76$ and 0.93 for hyssop, oregano and sweet basil, respectively. Error bars represent one standard error of mean

\section{Conclusions}

Three tested species germinated over a wide temperature range $\left(10-40{ }^{\circ} \mathrm{C}\right)$ under absolute darkness; however, hyssop germinated at $5^{\circ} \mathrm{C}$. Sweet basil and Hyssop showed almost fine germination responses at high temperature ( 40 ${ }^{\circ} \mathrm{C}$ ); furthermore, they demonstrated enhanced seedling growth at higher temperatures, so it can be inferred that higher germination activities at high temperatures could indicate further growth of seedling at warmer temperatures. According to the results of the segmented model, cardinal temperatures including base, optimum and maximum temperatures were various between $3.42-5.70{ }^{\circ} \mathrm{C}, 30$ ${ }^{\circ} \mathrm{C}$ and $42.91-48.05^{\circ} \mathrm{C}$ among species. Jami Al-Ahmadi and Kafi (2007) believed that the ability of seed germination at low temperatures and its rapid germination at high temperatures allows us to use species as a second crop, or to cultivate it twice a year; therefore, maximum utilization of resources can be obtained, especially in arid and semi-arid regions. It seems that the ability of hyssop to germinate at low temperatures and its rapid germination at high temperatures makes it a suitable species approving mentioned hypothesis. Here, we propose temperature range (TR) as an index that could show adaptation capability to broad sites for planting and domestication.

\section{References}

Ann MW, Binning L (1987). Calculating the threshold temperature of development for weeds. Weed Sci 35:177-179.

Brändel M (2006). Effects of temperatures on dormancy and germination in three species in the Lamiaceae occurring in northern wetlands. Wetlands Ecol Manage 14:11-28.

Chang X, Alderson PG, Wright CJ (2005). Effect of temperature integration on the growth 598 and volatile oil content of basil (Ocimum basilicum L.). J Hort Sci Biotechnol 80:593-598.

Copeland LO, McDonald MB (1995). Principles of Seed Science and Technology, 3rd Ed. Chapman and Hall, USA.

De Villiers AJ, Van Rooyan MW, Theron GK (2002). Germination strategies of strandveld succulent karoo plant species for revegetation purposes: I. Temperature and light requirements. Seed Sci Technol 30:17-33.

Estrelles E, Güemes J, Riera J, Boscaiu M, Ibars AM, Costa M (2010). Seed germination behaviour in Sideritis from different Iberian habitats. Not Bot Hort Agrobot Cluj 38(1):913.

Evans LT (1996). Crop evolution, adaptation and yield. Cambridge University Press, Cambridge, UK. p. 500.

Finch-Savage WE, Phelps K (1993). Using hydrothermal time to predict seedling emergence. J Exp Bot 44:407-414.

Flores J, Briones $\mathrm{O}$ (2001). Plant life-form and germination in a Mexican intertropical desert: effects of soil water potential and temperature. J Arid Environ 47:485-497.

Grime JP, Hodegson JG, Hunt R (1988). Comparative plant ecology: a functional approach to common British species, 1st Ed.Unwin Hyman, London, 742 pp.

Iannucci A, di Fonzo N, Martiniellp P (2000). Temperature requirements for seed germination in four annual clovers grown under low irrigation treatments. Seed Sci Technol 28:59-66.

Jami Al-Ahmadi M, Kafi M (2007). Cardinal temperature for germination of Kochia scoparia (L.). J Arid Environ 68:308314.

Kader MA, Jutzi SC (2004). Effects of thermal and salt treatments during imbibitions on germination and seedling growth of sorghum at $42 / 19^{\circ} \mathrm{C}$. J Agron Crop Sci 190:3538.

Kamkar B, Koocheki A, Mahallati MN, Moghaddam MPR (2006). Cardinal temperatures for germination in three millet species. Asian J Plant Sci 5:316-319.

Kocabas YZ, Karaman S (2001). Essential oils of Lamiaceae family from south east Mediterranean region (Turkey). Pak J Biol Sci 4(10):1221-1223.

Maguire JD (1962). Speed of germination-aid in selection and evaluation for seedling emergence and vigor. Crop Sci 2:176-177.

Mwale SS, Azam-Ali SN, Clark JA, Bradly RG, Chatha MR (1994). Effects of temperature on the germination of su- 
flower (Helianhtus annus L.). Seed Sci Technol 22:565-576.

Nykiforuk CL, Flanagan AMJ (1994). Germination and early seedling development under low temperature in canola. Crop Sci 34:1047-1054.

Olivier FG, Annandale JG (1998). Thermal time requirements for the development of green pea (Pisum sativum L.). Field Crops Res 56:301-307.

Otero-Arniaz A, Casas A, Bartolo C, Perez-Negron E, ValienteBanuet A (2003). Evolution of Polaskia chichipe (Cactaceae) under domestication in the Tehuacán Valley, central Mexico: reproductive biology. Am J Bot 90(4):593-602.

Phartyal SS, Thapliyal RC, Nayal JS, Rawat MMS, Joshi G (2003). The influences of temperature on seed germination seed rate in Himalayan elm (Ulmus wallichiana). Seed Sci Technol 31:83-93.

Putievsky E (1983). Temperature and day length influence on the growth and germination of sweet basil and oregano. J Hortic Sci 58:583-587.

Ramin AA (1997). The influence of temperature on germination of taree Irani (Allium ampeloprasum L. app. Iranicum W.). Seed Sci Technol 25:419-426.
Roberts EH (1988). Temperature and seed germination, p. 109-132. In: Long SP, Woodward FI (Eds.). Plants and temperature. Symp Soc Exp Biol, Company of Biologists Ltd, Cambridge.

Rojas Aréchiga M, Casas A, Vazquez-Yanes C (2001). Seed germination of wild and cultivated Stenocerevs stellatus (Cactacea) from the Tehuacan-Cuicatlan Valley, Central Mexico .J Arid Environ 49(2):279-287.

Soltani A, Galeshi S, Zenali E, Latifi N (2002). Germination seed reserve utilization and growth of chicpea as effects by salinity and seed size. Seed Sci Technol 30:51-60.

Soltani A, Robertson MJ, Trabi B, Yousefi M, Sarparast R (2006). Modeling seedling emergence in chickpea as affected by temperature and sowing depth. Agric Forest Meteorol 138:156-167.

Thanos CA, Kadis CC, Skarou F (1995). Ecophysiology of germination in the aromatic plants thyme, savory and oregano (Labiatae). Seed Sci Res 5:161-170. 